\title{
STUDENTS' LEARNING STYLES IN THE CLASSROOM AND IT'S IMPORTANCE TO EDUCATORS IN THE TEACHING AND LEARNING PROCESS: AN OVERVIEW
}

\author{
Baskaran Kannan,EdD ${ }^{1}$, Ganesan Shanmugavelu, $\mathbf{P h D}^{2}$, \\ Santhiran Arumugam, EdD ${ }^{3}$, Shobanah Menon Baskaran ${ }^{4}$, \\ Balakrishnan Parasuraman, $\mathbf{P h D}^{5}$ \\ ${ }^{I}$ Senior Lecturer, Institute of Teacher Education Ipoh Campus, Malaysia \\ ${ }^{2}$ Senior Lecturer, Institute of Teacher Education Ipoh Campus, Malaysia \\ ${ }^{3}$ Senior Teacher, Form Six College Tawau, Sabah, Malaysia \\ ${ }^{4}$ Research Assistant, Universiti Putra Malaysia \\ ${ }^{5}$ Professor, Universiti Malaysia Kelantan
}

Article DOI: https://doi.org/10.36713/epra8045

DOI No: 10.36713/epra8045

\begin{abstract}
This article discusses the various learning styles of students in the teaching and learning process in the classroom. Among the learning style models discussed in this article are such as Dunn and Dunn learning style model, Kolb learning style model, Felder Silverman learning style model, VAK learning style model, Visual, Audio, 'Read and Write' and Kinesthetic (VARK) learning style model, Honey and Mumford learning style model, Selmes learning style model. Each learning style model has its strengths and weaknesses. This, a good understanding and mastery of a learning style will allow teachers to help implement teaching and learning strategies that students are interested in according to their tastes. Furthermore, it can increase the interest and effectiveness of students in the teaching and learning process as well as improve the academic achievement of students.
\end{abstract}

KEYWORDS : Learning Styles, Teaching,Classroom, Educators, Academic Achievement

\section{INTRODUCTION}

Style means the way, manner and behaviour practised by students during the learning process (Joginder Singh, 2012). Learning, on the other hand, refers to the actions taken by students to seek new knowledge and experiences during the learning process (Harackiewicz \& Hulleman, 2010). According to Dunn and Dunn (1982), learning style refers to the way each student focuses, processes and stores new information. Learning style can also be defined as a change that occurs consistently involving the mind and physical to reflect a change in the form of action (Mohd Razimi Husin, Abd. Aziz Shukor \& Ahmad Jazimin Jusoh, 2011). Learning style can be seen when an individual can exhibit a new change either in the form of understanding or skills as well as used while studying.

Each student has his or her own style of receiving, processing, storing and recalling new information (Prabha, 2013). In short, learning style is the pattern, way or style of learning of an individual to parse, process, interpret the information obtained according to personal desires, wants and suitability. According to Kharb, Samanta, Jindal and Singh (2013), learning style is the method chosen by an individual to collect, process, interpret, organize and analyse information. Since the learning style is considered important in the process of becoming and succeeding students, then an educator must know the appropriate learning styles for students so that the 
objectives of teaching and learning can be achieved successfully. Proactive teachers will strive and ensure that teaching and learning are implemented based on learning styles that fits in with the abilities of students (Mohd Razimi Husin, Abd. Aziz Shukor \& Ahmad Jazimin Jusoh, 2011).

In fact, every student has their own learning style. An individual's learning style differs from one style to another according to the student's inclinations (Mohd Nasaruddin Mohd Noor \& Anuar Ahmad, 2014). Learning styles also differ according to the subjects studied by the students and the teacher's teaching (Sohaina Mohd Salleh, Maimun Aqsha Lubis \& Aisyah Sjahrony, 2017). Differences in learning styles affect the learning process and the ability to store information to students. The goal of learning style is not only to add knowledge and gain information, but even broader than that. Identifying and exploiting suitable learning styles can increase one's potential in a more effective learning process.

Suitable and accurate learning style is a determinant towards working on knowledge effectively. Teaching and learning processes that are in line with students' learning styles can result in a more proactive and constructive learning process (Ovez \& Uyangor, 2016). The selection of a suitable learning style is important for students to achieve the main goals of the subject and in turn can improve their academic achievement. The study of Graf, Liu and Kinshuk (2010), proved that student achievement will increase and show positive development if the learning style that is suitable to the capacity ability of students is given priority in the learning process. The way an individual chooses to approach a learning situation is able to affect their performance and achievement. According to Chambers in Nasirah Ismail, Norhasliza Abdullah and Siti Zubaidah (2010), students should use suitable learning styles as their strengths in academics.

Students' academic achievement is often associated with motivation, learning style and teaching methods (Maizatul Wahidar \& Mohd Roslan, 2011). Accordingly, students need to be exposed to effective and appropriate learning styles to enhance academic achievement excellence. According to Donald (2010), students who are introduced to the right learning style have produced more positive results than before. Learning style is also a guide and motivator to a student's learning process. Learning style is as well defined as the method or way a person learns to acquire knowledge. Furthermore, learning style refers to a learning approach that a student is interested in to acquire knowledge (Cheong, Chong $\&$ Ling, 2012). The information received will be stored in mind to be used when required.

Moreover, learning styles are said to be subjective. There is no such thing as the best learning style or any poor learning style. It all depends on the ability and suitability of the student based on his own choice. None of the learning styles exhibit the best way than the others. Similarly, there is no single learning style that can improve students' achievement in lessons (Azizi Yahya \& Syazwani Abdul Razak, 2010). There are learning styles that are suitable for certain students while for other students the style might not be suitable. If a student excels in his or her academic achievement, it is likely that the learning style he or she chose and practised suits him or her. Meanwhile, if a student does not excel in his or her academic, it is likely that the learning style he or she practised does not suit him or her (Meor Ibrahim Kamaruddin \& Assaadah Mohamad, 2011). Such students have to find a learning style that suits their nature so that it really has a positive effect on them.

\section{VARIOUS LEARNING STYLE MODEL}

The learning style has several models pioneered by some of the people figures. Among the models of learning styles are such as Dunn and Dunn learning style model, Kolb learning style model, Felder Silverman learning style model, VAK learning style model, Visual, Audio, 'Read and Write' and Kinesthetic (VARK) learning style model, Honey and Mumford learning style model, Selmes learning style model and so on.

\section{(a) Dunn and Dunn Learning Style Model}

Dunn and Dunn (1982) learning style model is based on three main principles. First, the learning style depends on a student's ability and capability of learning. Secondly, the style of learning depends on a student's ability and predilection. Thirds, environmental factors, learning materials and learning methods influence a student's learning style. The learning style is also often referred to the learning environment of the student in the most optimal way.

Furthermore, Dunn and Dunn's model of learning style stated that if the learning process is adapted according to the student's learning style, the level of achievement of the student can be improved (Dunn \& Dunn, 1982). According to Meor Ibrahim Kamaruddin and Assaadah Mohamad (2011), Dunn and Dunn's model of learning style stated that a student's learning style relies heavily on five main stimuli namely environment, emotion, sociology, physical and psychological. Below is the explanation of the five stimuli.

\section{(i) Environment}

The learning style that is influenced by environmental factors usually plays a direct role in the learning of a student. Among the environmental factors such as sound, light, climate and techniques as well as strategies have indeed influenced the learning style of the student. There are students who 
are more comfortable learning in a quiet atmosphere while others are comfortable learning in a sound atmosphere such as listening to songs. Referring to the temperature factor, there are students who can study in a bright light, cool atmosphere and some are vice versa (Dunn \& Dunn, 1982).

In addition, a student's personality influences the learning style. Student's personalities which are introvert and extrovert also influences their learning style. According to Chong, Chong and Ling (2012), students with introvert traits prefer formal learning styles while extroverts prefer informal learning styles. Introvert students are more individual in that their learning environment requires special tables and chairs and is not interested in sharing them with other students. While the students who are extrovert, they can learn anywhere despite the unconducive atmosphere of the place. Learning environment based on different environments usually create different learning styles among students. The preparation of certain learning environments for all students might not be appropriate. The techniques and learning strategies between one student and another student are indeed different (Meor Ibrahim Kamaruddin \& Assaadah Mohamad, 2011).

\section{(ii) Sociology}

Sociology also influences a student's learning style. The sociological aspects are largely dependent on the students themselves and followed by the influence of peers, groups, family and so on. There are students who are more confident in themselves and prefer to study alone and do not like to learn in groups or pairs. They are more confident in studying alone. On the other hand, there are students who like to learn with others in the form of groups. They are more interested in two-way learning which is more convincing. Group learning is encouraged as to make it easier for students to discuss and exchange views. Group learning method is more effective as it allows information to be stored longer in the students' memory (Meor Ibrahim Kamaruddin \& Assaadah Mohamad, 2011).

\section{(iii) Emotion}

Emotional factors equally influence a student's learning style. A student's success depends heavily on intrinsic and extrinsic motivation. Intrinsic motivation does not require external stimulation while extrinsic motivation depends on external factors to react. Meeting physiological and psychological needs becomes the primary goal of intrinsic motivation while extrinsic motivation is aimed at obtaining rewards in the form of existing objects or compliments (Meor Ibrahim Kamaruddin \& Assaadah Mohamad, 2011).

\section{(iv) Physical}

Senses are essential in helping us to remember the information we learn during the learning process. Physical elements. Such as perception, food, time and movement also influence a person's learning style. Through visual and audio elements, students gained a lot of information and experiences of their own. When the visual element of the student is more dominant, then the student tends to actively study using charts, pictures, graphs, videos, mobile phones, computers and so on. The usage of visual elements as teaching aid can speed up students' understanding and become a driving force for students to be interested in a subject in an effort to improve academic achievement level (Meor Ibrahim Kamaruddin \& Assaadah Mohamad, 2011).

Auditory elements in return enable students to learn in a relaxed environment where they can understand the contents of the lesson while listening to songs. This situation is considered as an advantage to the students because not all students can learn in this environment. Meanwhile, kinesthetic elements allow students to learn by using the sense of touch. Through touch and feel towards learning materials can improve the student's understanding. Kinesthetic learning atmosphere can also give stimulation and thus motivate them to continue learning level (Meor Ibrahim Kamaruddin \& Assaadah Mohamad, 2011).

\section{(v) Psychology}

Students who implement a learning style based on psychological factors will emphasise reflective, impulsive, global and analytical. Reflective students are always mindful and take their learning process seriously. Usually they will think carefully and decide after considering the information is logical and thoughtful. While impulsive students do not make any preparation for the learning process which causes rarely successful in the lessons. Analytical students love to learn in a comfortable atmosphere such as bright environment, adequate learning equipment and no noise disturbance from the surrounding. While students who practice a global learning style prefer to learn in a romantic environment without a complete learning equipment (Meor Ibrahim Kamaruddin \& Assaadah Mohamad, 2011).

The discussion above shows that, Dunn and Dunn's model of learning style is a learning process that gives priority to processing and remembering information about the content of the lesson.

\section{b) Kolb Learning Style Model}

The basic learning style of Kolb's model divides student learning style into four categories which is imaginative and creative, analytical theory, practical and dynamic intuitive (Kolb, 1984). Kolb's learning style and experiential learning cycle also 
divides the learning style into four cycles, namely concrete experience, reflective, abstract concepts and active experiments (McLeod, 2017). At the concrete experience level, students gain experience based on new situations they face. In the second stage, which is the reflection stage, students make observations and then reflect on new experiences that they have experienced. This experience is important for the formation of their understanding that leads to the formation of concepts. At this stage, a conflict between experience and understanding occurs (McLeod, 2017).

At the third stage, which is the abstract concept stage, new ideas will be formed as a result of reflection. At this stage, the formation of new ideas can be modified with existing abstract concepts in the student. The formation of these formed abstract concepts (analysis) and generalisations (conclusions) will be used in the next stage. Finally, at the active experimental stage, students are able to apply their ideas to a wider environment to see real situations. At this stage, they are also able to test hypotheses formed in future situations to produce more concrete new experiences (McLeod, 2017).

\section{(c) Felder-Silverman Learning Style Model}

Felder Silverman's model learning style is divided into four categories namely active and reflective, concrete and intuitive, visual and verbal as well as structured and global (Muruganandam \& Srinivasan, 2016).

\section{(i) Active and Reflective}

An active student likes to learn something in groups and likes to explain the content of the lessons to friends so that it is easy to remember something. Meanwhile, students who are reflective like to study alone and only after that explain to friends (Muruganandam \& Srinivasan, 2016).

\section{(ii) Concrete and Intuitive}

Concrete students are practically fact- and procedure- oriented. They are more realistic and concerned with accuracy in a work. However, intuitive students are conceptual, innovative and theory oriented. They are more innovative and value creativity in a job (Muruganandam \& Srinivasan, 2016).

\section{(iii) Visual and Verbal}

Visual students are fond of visual presentations such as diagrams and flow charts because it is easy to remember facts through sight. On the contrary, verbal students like written and oral presentations because it is easy to remember facts through listening (Muruganandam \& Srinivasan, 2016).

\section{(iv) Structured and global}

Students of structured character learn linearly and in detail. The learning process is described in an orderly manner and they like to focus on one thing only. On the other hand, students who are global in nature learn holistically. The learning process is described as a whole and they like to relate one thing to another (Muruganandam \& Srinivasan, 2016).

\section{(d) Visual, Audio and Kinesthetic (VAK) \\ Learning Style Model}

The figures who introduced the learning style of VAK model consisted of Fernald, Keller, Orton, Gillingham, Stillman, Montessori and others. Basically, the learning style of the VAK model consists of three components of learning style practised by students which are visual learning style, auditory learning style and kinesthetic learning style (Norul Haida Reduzan, Robe'ah Joseph \& Guidance Hasim, 2016).

Through visual learning styles, students learn using words and do not require detailed verbal explanations. The use of visual pictures, acting and video is used as the main learning source for the understanding of the students. While in auditory learning style, students use the auditory senses to obtain and remember information. Students read aloud and lip movements can be clearly seen. While the kinesthetic learning style involves learning activities that involve physical movement and students actively participate because there are group activities followed by audio (Norul Haida Reduzan, Robe'ah Joseph \& Guidance Hasim, 2016).

\section{(e) Honey and Mumford Learning Style Model}

Honey and Mumford's model learning style focusses on the experiences gained as a result of learning things. Linking new knowledge with old knowledge is part of Honey and Mumford's model learning style which allows students to draw their own conclusions. Honey and Mumford learning style model emphasises aspects of one's attitude and behaviour based on activist, reflective, theoretical and pragmatic learning style (Benny Hendriana, Budi Wayulu, Rochmad \& Mulyono, 2019).

\section{(i) Activist learning style}

Activist attitudes and behaviours emphasise a person's curiosity to something new for satisfaction. Students who are activists like to do challenging activities to gain new experiences and knowledge. Quick action to do something without thinking long causes them not to focus on the impact of such actions. Living independently, sociable, friendly and fond of social life are among the advantages of activist learning style practitioners (Benny Hendriana, Budi Wayulu, Rochmad \& Mulyono, 2019). Daily 
activities often hover around him of her alone without disturbing others.

\section{(ii) Reflective learning style}

Reflective learning style emphasises the experience gained by a student. Reflective learning style involves three phases, namely observation, thinking and reflection. Usually students will not make a decision in a hurry, however they are even more careful so that mistakes do not happen. Furthermore, the decisions of which have been taken or to be taken will always be reflected again. Students will also collect relevant information thoroughly to make accurate analysis based on the experience gained. Their observation of an event or action is more profound and focused. In short, students who practise reflective learning style tend towards subjects with a lot of practical use (Benny Hendriana, Budi Wayulu, Rochmad \& Mulyono, 2019).

\section{(iii) Theoretical learning style}

Students who practise the theoretical learning style have logical thinking along with rationale. Theories and models are the main pillars of their thinking. Theoretical learning style practitioners are less creative and make their own predictions based on the condition of the environment dependent on theory. However, conclusions or summaries made have strong evidence based on the analysis made use (Benny Hendriana, Budi Wayulu, Rochmad \& Mulyono, 2019).

\section{(iv) Pragmatic learning style}

Like theoretical learning style, students who practise pragmatic learning style also adhere to logic and rationality in the learning process. Their results are based on observations and strong evidences. The comparison process is also often practised by students to obtain accurate and logical answers. Typically, male students practise pragmatic learning style more compared to female students because the learning process is correlated with logic at the level of mind thinking (Benny Hendriana, Budi Wayulu, Rochmad \& Mulyono, 2019).

\section{(f) Visual, Audio, 'Read and Write' and} Kinesthetic (VARK) learning style model

The VARK learning style model was introduced and designed by Neil D. Fleming as a result of his own observations on learning problems in New Zealand. His observations found that there were problems in teachers' delivery and students' acceptance during the teaching and learning process which affects the performance of students. VARK learning style model presents four learning styles based on individual differences that are visual learning style, audio learning style, read-write learning style and kinesthetic learning style (Allen, Scheve \& Nieter, 2011).

\section{(i) Visual learning style}

Visual learning style has four inputs that are necessary and suitable to be applied which are teaching involving teachers, textbooks, teaching aids and writing. The teaching process is an important aspect that capable of describing things to be explained. The textbooks used focuses more on colourful drawings to attract the interest of the students. Meanwhile, the teaching aids are in the form of videos, charts, posters, pictures and slides. Finally, the writing is presented in various forms and colours as a way of attracting the attention of students (Allen, Scheve \& Nieter, 2011).

\section{(ii) Audio learning style}

The style of audio learning emphasises voice and sound learning. Students will learn through listening such as listening to lectures from their teachers, receiving explanations and so on. In order to achieve the audio learning style, students need to attend to school and follow the teaching and learning process as scheduled. Discussion methods among students are encouraged in the learning process (Allen, Scheve \& Nieter, 2011).

\section{(iii) Read-write learning style}

The learning style of reading-writing uses notes, prioritises facts, and encourages the search for information among students. Using words, vocabulary and building structured sentences are given priority. Moreover, explanations in the form of essays are considered to be the best learning process (Allen, Scheve \& Nieter, 2011).

\section{(iv) Kinesthetic learning style}

Kinesthetic learning style uses all five senses which are sight, sound, smell, taste and touch. Learning activities such as the use of laboratory, study visits and so on are applied in this type of learning. The application of learning theory in real-world situations and practical training often colour the world of kinesthetic learning style. Learning techniques such as learning by the method of trial and error and experimental methods are also implemented to solve a particular problem in learning (Allen, Scheve \& Nieter, 2011).

In conclusion, there are three basic principles in the learning style of the VARK model. First, master the level of mastery of the lesson contents. Secondly, the level of motivation increases when learning in a conducive and complete learning environment. Third, a new training should be given as an encouragement and inspiration in the students' learning. 
(g) Selmes Learning Style Model

Selmes learning style model is measured using the instrument of 'Learning Inventory in Schools'. The four learning styles of the Selmes model consist of surface learning style, depth learning style, organised learning style and hard work learning style.

\section{(i) Surface learning style}

Surface learning style is dependent on students. According to the surface learning style, students will only respond when directed. This learning style indicates that students will only perform lessons after being instructed by others. Usually the student depends or waits for instruction from the teacher. As a result of relying too much on the instruction of teacher, the student is usually unable to understand the lessons he or she is learning in depth. Student will only memorise the facts they learned and consider those facts have no any connections between one and another. As a result, students have no ability to associate a fact or concept with another fact or concept (Selmes, 1987).

\section{(ii) Depth learning style}

The style of depth learning relates to the student's curiosity towards the knowledge they are learning. Students will have a high interest in the content of the lesson. Students also look for implied facts to relate to the concepts they are studying. In short, students will show interest in the content of the lesson and love to understand it deeply. As a result, students can easily link new information with existing experiences and knowledge. Students using depth learning style will continue to try to understand deeply the content of the lessons learned (Selmes, 1987).

\section{(iii) Hard work learning style}

The hard work learning style goes against the surface learning style. Students who apply the hard work learning style will strive hard to learn the contents of the lesson without the instruction from other parties especially from teachers. In order to achieve excellence in education, students will work on their own and will explore knowledge to improve their understanding of the lesson contents. Students will also make an effort themselves to make notes, review, create additional exercises and will try to solve their learning problems on their own (Selmes, 1987).

\section{(iv) Organised learning style}

In an organised learning style, students usually manage their own learning time. Distinctive learning time planning usually has a positive impact on their academic achievements. This situation will encourage students to compose their lessons regularly and systematically. Furthermore, students are able to formulate their answers in order before they can answer any questions during the examination (Selmes, 1987).

Selmes learning style model classifies that the learning style is the driver of students' learning. In fact, it can guide students to know how to learn appropriately and motivates them to engage in their learning actively and effectively. According to Habsah Mohamed and Arsmir Amir (2014), Selmes learning style model (1987) introduces a rather different perspective by focusing on the difference in learning style possessed by each individual. The learning style of Selmes model (1987) emphasises the concept of self-reliance learning, elements of competing among students, the production of quality work, hard work and organised learning. Besides that, Selmes model also discussed in depth on training aimed at encouraging students to be independent and not just expect and rely on others.

\section{CONCLUSION}

There are various positive effects on teachers and students on understanding a good learning style. A good mastery of a learning style will enable the teacher to help explain the learning strategies that students are interested in according to their taste. On the teachers' part, teachers can plan and implement suitable teaching strategies so that the students can understand them easily. Teachers can play a role in helping students to engage themselves in exploring learning strategies that are suitable and effective for themselves (Selmes, 1987). This can be concluded that students' failures in academic field may be avoided if the appropriate learning style is fully identified and practised. In this regard, the teaching and learning approach should use the approach of learning style models that is in line with the students' abilities and interests. The appropriate learning style model can help students to learn and understand learning approach, help to enhance self-strength and identify situations that can help towards the effectiveness of learning (Morrow, 2011).

\section{REFERENCES}

1. Allen, K., Scheve, J., \& Nieter, V. (2011). Understanding learning styles: Making a difference for diverse learners. Huntington Beach: Shell Education Publishing.

2. Azizi Yahaya \& Syazwani Abdul Razak. (2010). Teori berkaitan gaya pembelajaran dan kaedah pengajaran. Dicapai daripada http://www.researchgate.net/publication/ 46480625.

3. Benny Hendriana, Budi Wayulu, Rochmad \& Mulyono. (2019). Kemampuan komunikasi Matematis siswa berdasarkan gaya belajar Honey dan Mumford. Dicapai daripada 
http://www.264-Article

Text-1288-1-1020200129(1).pdf.

4. Cheong, E., Chong, S. C., \& Ling, H. N. (2012). Psikologi Pendidikan: Gaya pembelajaran. Dicapai daripada dpliprasekolahsunshineblogsport.com.>by-evacheong-s.

5. Donald, M. O. (2010). Hubungan antara motivasi, gaya pembelajaran dan iklim bilik kuliah terhadap pencapaian akademik murid tingkatan empat. Tesis Sarjana Muda Tidak Diterbitkan. Universiti Teknologi Malaysia.

6. Dunn, R., \& Dunn, K. (1982). Teaching students through their individual learning style: A practical approach. Massachusets: Prentice Hall.

7. Graf, S., Liu, T. C., \& Kinshuk. (2010). Analysis of learners navigational behavior and their learning styles in an online course. Journal of Computer Assisted Learning, 26(2), 116131.

8. Habsah Mohamed \& Ruslin Amir. (2014). Hubungan gaya pengajaran guru terhadap gaya pembelajaran dan pencapaian pelajar tingkatan empat di Putrajaya. Tesis Sarjana Tidak Diterbitkan. Universiti Kebangsaan Malaysia.

9. Harackiewicz, J. M., \& Hulleman, C. S. (2010). The impotance of interest: The role of achievement goals and task values in promoting the development of interest. Social and Personality Psychology Compass, 4(1), 42-52.

10. Joginder Singh, R. K. (2012). Panduan ilmu pendidikan untuk DPLI falsafah dan etika. Kuala Lumpur: Budiman Sdn.Bhd.

11. Kharb, P., Samanta, P. P., Jindal, M., \& Singh, V. (2013). The learning styles and the preferred teaching-learning strategies of first year medical students. Journal of Clinical and Diagnostic Research, 7(6), 1089-1092.

12. Kolb, D. A. (1984). Experiential learning: Experience as the source of learning and development. Englewood Cliffs, N.J: PrenticeHall.

13. Maizatul Wahidar \& Mohd Roslan. (2011). The influence of students' learning styles on academic achievements. Unpublished Master Thesis. Universiti Utara Malaysia.

14. McLeod,xS.xA.x(2017).xKoldxlearningxstylesxan dxexperientialxlearningxcycle.Dicapaixdaripada https://www.simplyp sychology.org/learningkolb.html

15. Meor Ibrahim Kamaruddin \& Assaadah Mohamad. (2011). Kajian gaya pembelajaran dalam kalangan pelajar UTM. Journal of Educational Psychology and Counseling, 2, 5177.

16. Mohd Nasaruddin Mohd Noor \& Anuar Ahmad. (2014). Gaya pembelajaran pelajar cemerlangxdalamxkalanganxpelajarxUniversitix KebangsaanxMalaysia.xTesis Sarjana Tidak Diterbitkan. Universiti Kebangsaan Malaysia.

17. Mohd Razimi Husin, Abd. Aziz Shukor \& Ahmad Jazimin Jusoh. (2011). Gaya pembelajaran dan persekitaran yang mempengaruhi murid sukar belajar dalam mata pelajaran Pendidikan Islam dan j-QAF: Satu kajian rintis. Jurnal Penyelidikan Dedikasi, 3, 98110.
18. Morrow, V. M. (2011). The relationship between the learning styles of middle school students and the teaching and learning styles of middle school teachers and the effects on student achievement of students' learning styles and teachers' learningxandxteachingxstyle.xDicapaixdaripadax $w w w$. researchgate.net $>$ publication 336920655 Teaching_styles.

19. Muruganandam, S., \& Srinivasan, N. (2016). Appraisal of Felder-Silverman learning style model with discrete data sets. Indian Journal of Science and Technology, 9(10), 1-4.

20. Nasirah Ismail, Norhasliza Abdullah \& Siti Zubaidah Saharudin. (2010). Hubungan motivasi, gaya pembelajaran dengan pencapaian Matematik Kejuruteraan: Tinjauan dalam kalangan pelajar semester akhir Diploma Kejuruteraan

Politeknik $=$ Sultan $=$ Azlan $=$ Shah.$=$ Dicapa $=$ darip ada=nasirah@psas.edu.my,hasliza@psas.edu.my ,siti_zubaidah@psas.edu.my

21. Norul Haida Reduzan, Robe'ah Yusuf \& Hidayah Hasim. (2016). Aplikasi model VAK dalam gaya pengajaran dan pembelajaran komsas Bahasa Melayu.

Dicapai daripada=http://conference.kuis.edu.my/recit201 6/images/eproceeding/DR-NORULHAIDA.pdf.

22. Ovez, F. T. D., \& Uyangor, S. M. (2016). The effect of the match between the learning and teaching style of secondary school Mathematics teachers on students' achievement. Journal of Education and Practice, 7(29), 125-132.

23. Prabha, V. (2013). Learning styles among the first year dental students. International Journal of Health Sciences and Research, 3(9), 22-28.

24. Santo, E. E., Soares, C. Q., Silveira, E. C. F., \& Costa Oliveira, R. P. (2015). A learning styles comparative study from high level students of face to face and distance education. Debate Universitario, 4(7), 55-68.

25. Selmes, L. P. (1987). Improving study skill: Changing perspective in education. Great Britain: Hodder and Stoughton Ltd.

26. Sohaina Mohd Salleh, Maimun Aqsha Lubis \& Aisyah Sjahrony. (2017). Pembangunan model gaya pembelajaran satu analisis keperluan di sekolah kebangsaan. ASEAN Comparative Education Research Journal on Islam and Civilization, 1(1), 54-63.

27. Zati Azmira Jaafar, Farah Nur-Rashida Rosnan \& Norfaezah Mohd Hamidin. (2019). Penilaian gaya pembelajaran VAK dalam kalangan pelajar Bahasa Arab di IPTS. e-Prosiding Persidangan Antarabangsa Sains Sosial dan Kemanusiaan. Kolej Universiti Islam Antarabangsa, 24-25 April. 